\title{
Revision of Dromilites bucklandii (Crustacea, Decapoda, Brachyura): Type material revealing its real identity, a junior synonym, and a new species
}

\author{
Barry W.M. van Bakel, Ninon Robin, Sylvain Charbonnier, and Jeff Saward
}

\begin{abstract}
Some of the fossil crabs from the lower Eocene London Clay have recently been the subject of several revisions, among them the exquisitely preserved dromiid (sponge) crabs. We examined Milne Edwards' original type material of Dromilites bucklandii, which appears different from all subsequently figured specimens by later authors. The type of $D$. bucklandii is conspecific with the much later described $D$. simplex Quayle and Collins, 1981. Specimens typically referred to as $D$. bucklandii by subsequent authors, of whom Bell (1858) is the most referred to, are here formally described as a new species, $D$. belli $\mathrm{n}$. sp. This new species is described based on Bell's figured material and novel specimens, which show marked ontogenetic variation in the carapace areolation. To document ontogenetic variation and sexual dimorphism, we studied size ranges, variation in ornamentation, and sex (which in many occasions could be determined because the abdomen was preserved) for all examined material. These comparisons rely on the new imaging of measured specimens, which had hitherto been unavailable for research. We provide through this study the description and figuring of type material, which had only been coarsely described (and often non-figured) by ninteenth century researchers. This improves our knowledge of extinct brachyurans; we here provide figures of all British type specimens of Dromilites.
\end{abstract}

*Barry W.M. van Bakel. Oertijdmuseum De Groene Poort, Bosscheweg 80, 5283 WB Boxtel, the Netherlands; and Naturalis Biodiversity Center, P.O. Box 9517, 2300 RA Leiden, the Netherlands. barryvanbakel@gmail.com

*Ninon Robin. Muséum national d'histoire naturelle, Centre de Recherche sur la Paléobiodiversité et les Paléoenvironnements (CR2P, UMR 7207), Sorbonne Universités-MNHN, CNRS, UPMC-Paris6, 57 rue Cuvier, Case postale 48, F-75005, Paris, France. ninon.robin@mnhn.fr

Sylvain Charbonnier. Muséum national d'histoire naturelle, Centre de Recherche sur la Paléobiodiversité et les Paléoenvironnements (CR2P, UMR 7207), Sorbonne Universités-MNHN, CNRS, UPMC-Paris6, 57 rue Cuvier, Case postale 48, F-75005, Paris, France. scharbonnier@mnhn.fr

http://zoobank.org/AB1D6EA7-643C-41EE-B160-2E9C5AB4C18F

Van Bakel, Barry W.M., Robin, Ninon, Charbonnier, Sylvain, and Saward, Jeff. 2017. Revision of Dromilites bucklandii (Crustacea, Decapoda, Brachyura): Type material revealing its real identity, a junior synonym, and a new species. Palaeontologia Electronica 20.3.61A: 1-12. https://doi.org/10.26879/813

palaeo-electronica.org/content/2017/2077-eocene-dromiid-crabs-revised

Copyright: December 2017 Paleontological Society.

This is an open access article distributed under the terms of Attribution-NonCommercial-ShareAlike 4.0 International (CC BY-NC-SA 4.0 ), which permits users to copy and redistribute the material in any medium or format, provided it is not used for commercial purposes and the original author and source are credited, with indications if any changes are made.

creativecommons.org/licenses/by-nc-sa/4.0/ 
Jeff Saward. 53, Thundersley Grove, Thundersley, Essex, SS7 3EB, United Kingdom. jeffsaward@gmail.com

${ }^{*}$ Both first authors contributed equally to the article

Keywords: Crabs; Dromioidea; Eocene; synonymy; ontogeny; new species; London Clay

Submission: 31 July 2017 Acceptance: 20 November 2017

\section{INTRODUCTION}

Improving knowledge of fossil diversity may be extremely dependent on the accessibility of the type material, sometimes not figured, and most of the time very generally described by nineteenth century researchers. The fossil crab species Dromilites bucklandii has been widely reported by paleontologists in the Eocene of Europe. Authorship of Dromilites bucklandii is ascribed to $\mathrm{H}$. Milne Edwards, who described it in 1837 after material from the Eocene of the Isle of Sheppey deposited at the Muséum d'Histoire Naturelle de Paris, and erected the genus Dromilites without assigning it any species nor providing its description. Thus considered as a nomen nudum for 20 years, the genus Dromilites was formally erected in 1858 by Bell, who provided its first description and put the previously described Dromia bucklandii Milne Edwards, 1837, as a species of the genus and figured the species with a series of English specimens housed at the Natural History Museum of London. Subsequent studies dealing with $D$. bucklandii always published the species as described in Bell (1858), without referring to Milne Edwards' original type material (e.g., Beurlen, 1928; Glaessner, 1929; Wrigley, 1945; Schweitzer and Feldmann, 2010; Quayle and Collins, 2012). In 1981, Quayle and Collins described a new species, rarer than D. bucklandii (sensu Bell, 1858), displaying much flatter and smoother carapace regions that they named $D$. simplex. After examination of the type material of Milne Edwards housed in the $\mathrm{MNHN}$, we evidence here that the species described in Bell (1858) and widely used by subsequent authors is not conspecific to that of $\mathrm{H}$. Milne Edwards (1837a). Further to this observation, we herein study ancient and new specimens of Dromilites by providing good imaging and comment on the features and ontogenetic changes of different morphotypes.

\section{MATERIAL AND METHODS}

Institutional Abbreviations

HMCMS: Hampshire Museum's Collections, United Kingdom; MNHN.F: Collection de Paléontologie, Muséum national d'Histoire naturelle, Paris, France; NHMUK PI: Collection of Invertebrate Paleontology, Natural History Museum, London, United Kingdom; MAB, Oertijdmuseum De Groene Poort collections, Boxtel, the Netherlands.

\section{Anatomical Abbreviations}

$\mathbf{C L}$, carapace length (exclusive of rostrum); CW, carapace width (excluding lateral spines); FM, frontal margin width; OFM, orbitofrontal margin width; PM, posterior margin width.

\section{SYSTEMATIC PALAEONTOLOGY}

Order DECAPODA Latreille, 1802

Infraorder BRACHYURA Latreille, 1802

Section PODOTREMATA Guinot, 1977

Subsection DYNOMENIFORMIA Guinot, Tavares and Castro, 2013

Superfamily DROMIOIDEA De Haan, 1833

Family DROMIIDAE De Haan, 1833

Subfamily SPHAERODROMIINAE Guinot and Tavares, 2003

Genus DROMILITES H. Milne Edwards in Bell, 1858

1837b Dromilite H. Milne Edwards; H. Milne Edwards, p. 255 (nomen nudum).

1837c Dromilite H. Milne Edwards; H. Milne Edwards, p. 115-116 (nomen nudum).

1838 Dromilite H. Milne Edwards; H. Milne Edwards, p. 482 (nomen nudum).

1858 Dromilites H. Milne Edwards; Bell, p. 27-29.

1929 Dromilites H. Milne Edwards; Glaessner, p. 139.

1969 Dromilites H. Milne Edwards; Glaessner, p. R487 and subsequent authors.

Type species. Dromia bucklandii $\mathrm{H}$. Milne Edwards, 1837a, by subsequent designation of Glaessner (1929). 
Included species. Dromilites bucklandii $(\mathrm{H}$. Milne Edwards, 1837a) (as Dromia bucklandi) (=D. simplex Quayle and Collins, 1981); D. pastoris Via, 1959; D. vicensis Barnolas Cortinas, 1973; ?Dromilites cardwelli (Armstrong, Nyborg, Bishop, OssóMorales, and Vega, 2009, as Pithonoton); D. montenati Robin, Van Bakel, Pacaud, and Charbonnier, 2016; D. belli n. sp.

Remarks. The nomenclature of Dromilites has been quite problematic, as stated by Quayle and Collins (1981), Schweitzer and Feldmann (2010), Guinot et al. (2013), and Robin et al. (2016). Here we follow the nomenclatural resolution of these latter authors (Dromilites H. Milne Edwards in Bell, 1858). As for included species, we note that Pithonoton cardwelli Armstrong, Nyborg, Bishop, OssóMorales, and Vega, 2009, Dromilites? by Schweitzer and Feldmann (2012), is discussed and transferred to Pithonoton again by Ossó (in press).

Dromilites bucklandii (H. Milne Edwards, 1837a) Figure 1, Table, and Appendix

1837a Dromia bucklandii $H$. Milne Edwards; $H$. Milne Edwards, p. 178-179.

1981 Dromilites simplex Quayle and Collins; Quayle and Collins, p. 736-737, pl. 104, figs. 1-3, 10 (nov. syn.)

1991 Dromilites simplex Quayle and Collins; Müller and Collins, p. 62.

2001 Dromilites simplex Quayle and Collins; Guinot and Tavares, p. 531.

2006 Dromilites simplex Quayle and Collins; Collins and Saward, p. 68, table 1.

2009 Dromilites simplex Quayle and Collins; Rayner et al., p. 55.

2009 Dromilites simplex Quayle and Collins; Van Bakel et al., p. 56.

2010 Dromilites simplex Quayle and Collins; Schweitzer et al., p. 64.

2010 Dromilites simplex Quayle and Collins; Schweitzer and Feldmann, p. 423-425, figs. 4-5.

2012 Dromilites simplex Quayle and Collins; Schweitzer and Feldmann, p. 594.

2012 Dromilites simplex Quayle and Collins; Quayle and Collins, p. 36, table 1-2.

2016 Dromilites simplex Quayle and Collins; Artal et al., 2016, p. 443.

Type material. H. Milne Edwards (1837a) did not report if there was more than one specimen included in his type series. Only one syntype is housed in the palaeontological collections of the MNHN, Paris, in H. Milne Edwards' collection (labeled "bucklandi", "Sheppey (Angleterre)", "Eocène", with a Milne-Edwards catalog number).
We select this specimen MNHN.F.B21561 to be the lectotype (see Figure 1a-1c).

Additional material examined. NHMUK PI IC 34026 (Spencer coll.) (male, London Clay, Highgate, London, $\left.51^{\circ} 34^{\prime} 18.29^{\prime \prime} \mathrm{N} / 0^{\circ} 9^{\prime} 0.82 " \mathrm{~W}\right)$; NHMUK PI In.28173 (Venables coll.) (London Clay, Bognor Regis, Sussex, $\quad 50^{\circ} 46^{\prime} 58.82^{\prime \prime} \mathrm{N} / 0^{\circ} 40^{\prime} 23.00^{\prime \prime W}$ ); NHMUK PI In.61700 (Elmore Formation, Unit 7, Lee-on-the-Solent, Hampshire, $50^{\circ} 48^{\prime} 7.54 " \mathrm{~N} /$ $\left.1^{\circ} 12^{\prime} 8.47 " \mathrm{~W}\right) ;$ NHMUK PI IC 548 (London Clay); MAB.k. 3590 (Isle of Sheppey, foreshore exposure, Kent, United Kingdom, 51 $\left.20^{\circ} 36.77^{\prime \prime N} / 1^{\circ} 0^{\prime} 2.76 " E\right)$, figured in Rayner et al., 2009, p. 55 (Isle of Sheppey foreshore exposure, Kent, United Kingdom) (see Table).

Remarks on type specimens. H. Milne Edwards (1837a) described, but did not figure Dromia bucklandii. Bell (1858) was the first to use Milne Edwards' species including it in Dromilites, and published a plate with figures of specimens currently held at the NHMUK (Wetherell coll.). His description is clearly based on these figured specimens. Specimens conspecific to Bell's species have been referred to as $D$. bucklandii by all subsequent authors, such as Quayle and Collins (1981) and Schweitzer and Feldmann (2010). However, none of these authors have apparently examined the original type material of Milne Edwards. One syntype of $D$. bucklandii, MNHN.F.B21561, is still housed in the MNHN collections (see Figure 1C) and has never been figured or referred to in later works on the species. After careful examination, it appears that this specimen has a rather smooth carapace preserved with the cuticle with regions not strongly inflated or marked with strong tubercles. It is not conspecific to the material figured and described by Bell (1858), as further explained below. This means that Bell (1858) described and figured specimens that did not correspond to $D$. bucklandii (this has no influence on the type species designation of Dromilites, which is only a nomenclatural act, and Bell was the first to use the species for this genus).

Quayle and Collins (1981) described D. simplex. They discussed (p. 737) that "the absence of marked tuberculation throughout these stages, together with weakly developed, non-bifurcated marginal spines and lack of transverse tubercles on the urogastric lobe immediately distinguishes this species from $D$. bucklandii." When comparing to $D$. bucklandii they obviously referred to the specimens figured and described by Bell (1858), but not to the type material of $\mathrm{H}$. Milne Edwards. Now having examined both the type material of $D$. bucklan- 


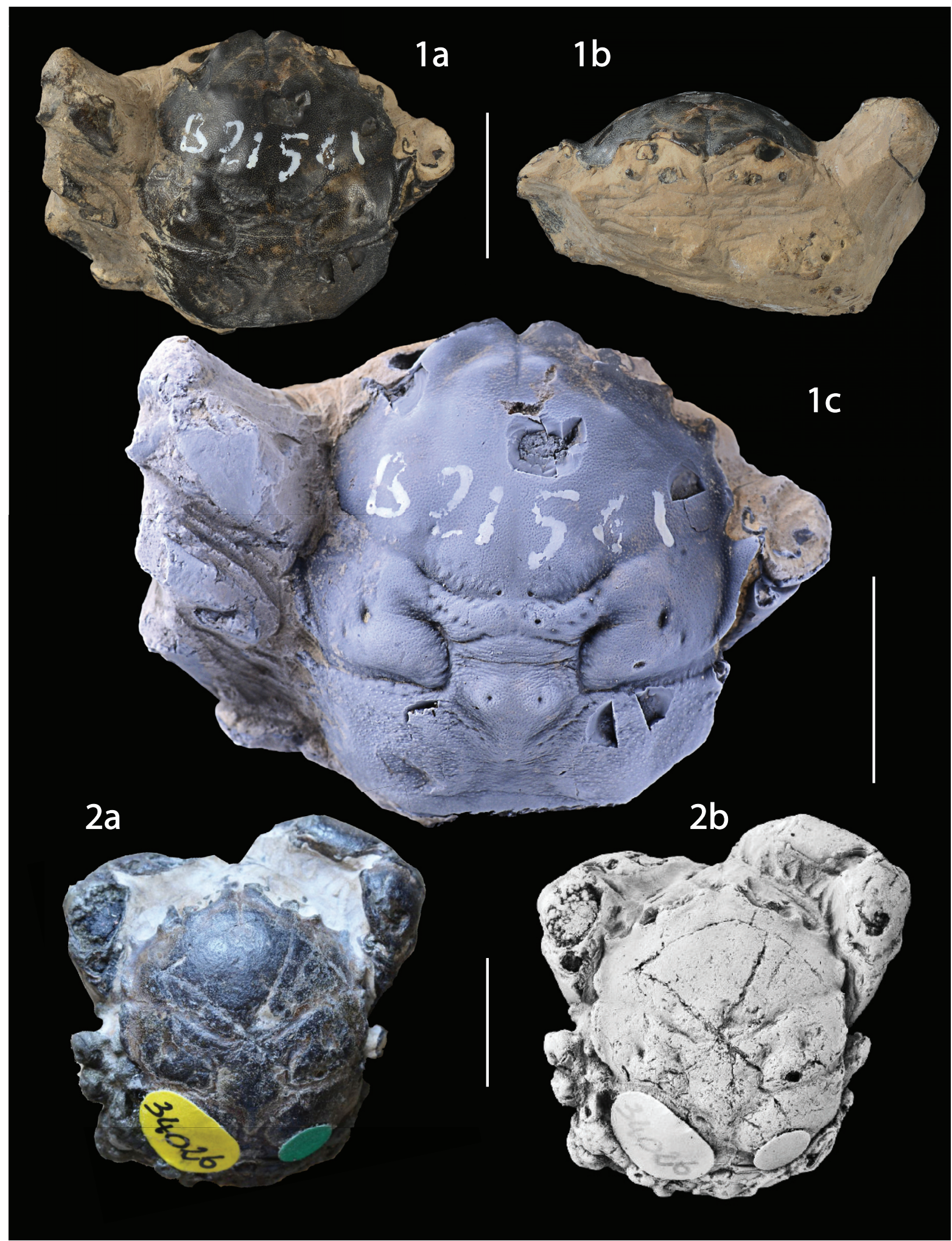

FIGURE 1. Dromilites bucklandii H. Milne Edwards, 1937. 1. Lectotype MNHN.F.B21561: (London Clay, Isle of Sheppey, Kent, United Kingdom): 1a. carapace in dorsal view, 1b. carapace in frontal view, 1c. carapace coated with ammonium chloride in dorsal view, 2. Holotype NHMUK PI IC 34026 (London Clay, Highgate, London, UK; Spencer coll.) of Dromilites simplex, nov. syn. of $D$. bucklandii: $2 a$. colored dorsal view, 2b. black and white dorsal view. Scale bars equal $10 \mathrm{~mm}$. Photographs: Lilian Cazes (1) and Barry van Bakel (2). 
TABLE. Comparative carapace lengths of both examined material of Dromilites bucklandii H. Milne Edwards, 1837 and Dromilites belli $\mathrm{n}$. sp.

\begin{tabular}{|c|c|c|c|c|c|c|c|}
\hline \multicolumn{8}{|c|}{ Carapace lengths of the examined material of Dromilites } \\
\hline D. bucklandii & $\begin{array}{l}\text { Carapace } \\
\text { length } \\
\text { (in } \mathrm{mm} \text {, } \\
\text { excluding } \\
\text { rostrum) }\end{array}$ & $\begin{array}{l}\text { Carapace } \\
\text { width } \\
\text { (in } \mathrm{mm} \text {, } \\
\text { excluding } \\
\text { lateral } \\
\text { spines) }\end{array}$ & Sex & D. belli n. sp. & $\begin{array}{l}\text { Carapace } \\
\text { length } \\
\text { (in } \mathrm{mm} \text { ) }\end{array}$ & $\begin{array}{l}\text { Carapace } \\
\text { width } \\
\text { (in } \mathbf{m m} \text {, } \\
\text { excluding } \\
\text { lateral } \\
\text { spines) }\end{array}$ & Sex \\
\hline NHMUK PI In.61700 & 14.2 & 16.22 & unknown & MNHN.F.R03853 & 17.5 & 18.2 & unknown \\
\hline NHMUK PI In.28173 & 16.1 & 15.5 & unknown & MAB.k 3583 & 17.5 & 19.7 & unknown \\
\hline NHMUK PI IC 548 & 20.1 & 14.6 & female & MNHN.F.A66911 & 21.5 & 19.5 & unknown \\
\hline MNHN.F.B21561 & 21.5 & 21.4 & unknown & MNHN.F.R03854 & 29 & 27 & unknown \\
\hline $\begin{array}{l}\text { NHMUK PI IC } \\
34026\end{array}$ & 22.3 & 18.5 & male & NHMUK PI OR 59089 & 32 & 31.5 & female \\
\hline MAB.k 3590 & 24 & 21 & unknown & Rayner et al., 2009, p.56 & 33,5 & 31 & female \\
\hline \multirow{2}{*}{$\begin{array}{l}\text { Rayner et al., } 2009 \text {, } \\
\text { p.55, 'sp. 1' }\end{array}$} & 26 & 21.5 & unknown & MAB.k 3586 & 25 & 23 & male \\
\hline & & & unknown & NHMUK PI OR 59091 & 35,5 & 37 & male \\
\hline
\end{tabular}

dii and $D$. simplex, we can conclude that the latter is a junior synonym of $D$. bucklandii.

Description. Carapace subovate, length slightly exceeding width (holotype dimensions: $C L=21.5$ $\mathrm{mm}, \mathrm{CW}=19.5 \mathrm{~mm}, \mathrm{FM}=7.5 \mathrm{~mm}$, OFM= $14 \mathrm{~mm}$, $\mathrm{PM}=11.2 \mathrm{~mm}$ ), maximum width at midlength, convex in longitudinal cross section, strongly convex in transverse cross section; orbitofrontal margin prominent, wide, $72 \%$ maximum carapace width. Rostrum projected beyond orbits, large, broadly triangular, bilobed, axially notched, frontal margin slightly convex; orbits forwardly, outwardly directed, upper orbital margin concave, outer orbital corner angular. Lateral margin angular in cross section; anterolateral margin weakly convex, with three strong teeth two anterior, one posterior to cervical notch; anterior two teeth pointed triangular; third lateral spine prominent, flattened anteriorly, outwardly directed, posteriorly forming flanged lateral margin with four to five granules. Posterolateral margin short, anteriorly straight, posteriorly strongly curved, anteriorly bearing single small forwardly directed tooth. Posterior margin slightly shorter than orbitofrontal margin, straight, rimmed.

Carapace regions rather smooth, marked by acute, shallow grooves; small epigastric swellings closely spaced, separated by short sulcus, mesogastric region undefined anteriorly, posteriorly only at base, wide, without tubercles, indistinct median groove. Protogastric regions flat; hepatic region inclined. Metagastric region trapezoidal, wide anteriorly, posterior margin inverted V-shape, surface laterally with oblique line of four to five pits, medially with indistinct paired gastic pits. Urogastric region low, triangular, apex directed forwards. Cardiac region weakly inflated, diamond-shaped, apex pointed posteriorly, centrally bearing two horizontally lined low bumps, pitted; intestinal region large, flat. Branchial region large, subdivided by oblique postcervical, branchial grooves; epibranchial, mesobranchial regions weakly vaulted; metabranchial region large, weakly vaulted.

Cervical groove widely V-shaped, deep, distinct on medial carapace, interrupted at axis by gastric pits, faint laterally, weakly notching carapace margin; branchial grooves more horizontal than cervical groove, acute, distinctly notching lateral margin; post-cervical grooves shallow, indistinct, conspicuously short; branchiocardiac grooves deep, curved, posteriorly converging to intestinal region.

Carapace epicuticle with numerous evenly spaced setal pits, microgranules. Internal mold and its ornamentation unknown.

Range. London Clay, Ypresian, lower Eocene.

Occurrence. London and Hampshire basins.

Dromilites belli $\mathrm{n}$. sp.

Figures 2-3, Table and Appendix zoobank.org/951EDF0C-6E01-445F-9E6F-45EB3E3B0D75

v. 1858 Dromilites bucklandi $\mathrm{H}$. Milne Edwards; Bell, p. 31-32, pl. VI, figs. 1-11.

v. 1898 Dromilites bucklandi H. Milne Edwards; Carter, p. 18.

v. 1906 Dromilites bucklandi H. Milne Edwards; Schröder, p. 7. 


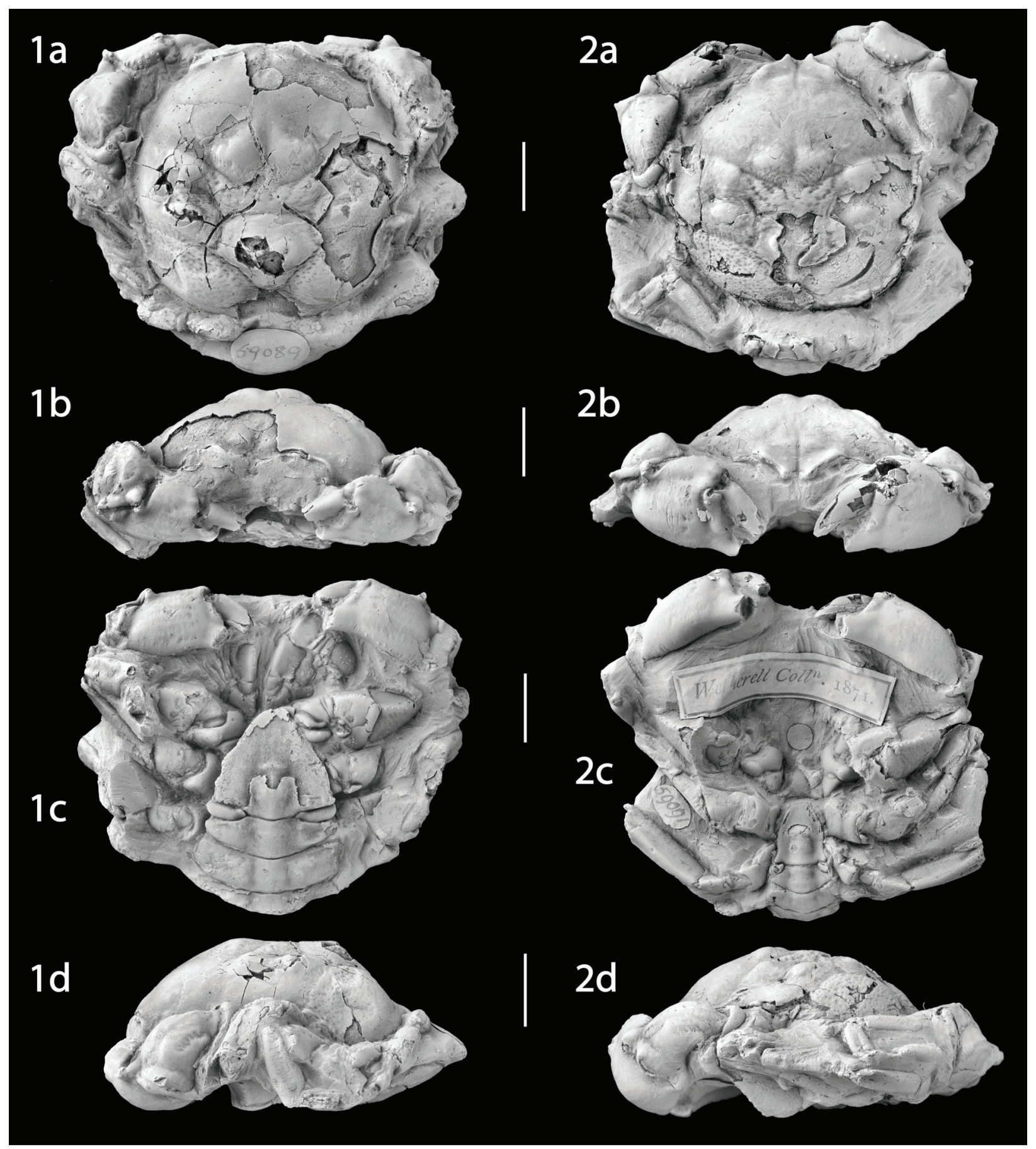

FIGURE 2. Dromilites belli n. sp. type series from the Ypresian ef London Clay (Copenhagen Fields, London, United Kingdom). 1. Holotype NHMUK PI OR 59089 (Wetherell coll.) coated with ammonium chloride (female individual): 1a. carapace in dorsal view, $1 \mathrm{~b}$. carapace in frontal view, 1c. carapace in ventral view, $1 \mathrm{~d}$. carapace in left-lateral view; 2. Paratype NHMUK PI OR 59091 (Wetherell coll.) coated with ammonium chloride (male individual): 2a. carapace in dorsal view, 2b. carapace in frontal view, 2c. carapace in ventral view, 2d. carapace in left-lateral view. Scale bars equal 10 mm. Photographs: Philip Hurst, Natural History Museum, London. 


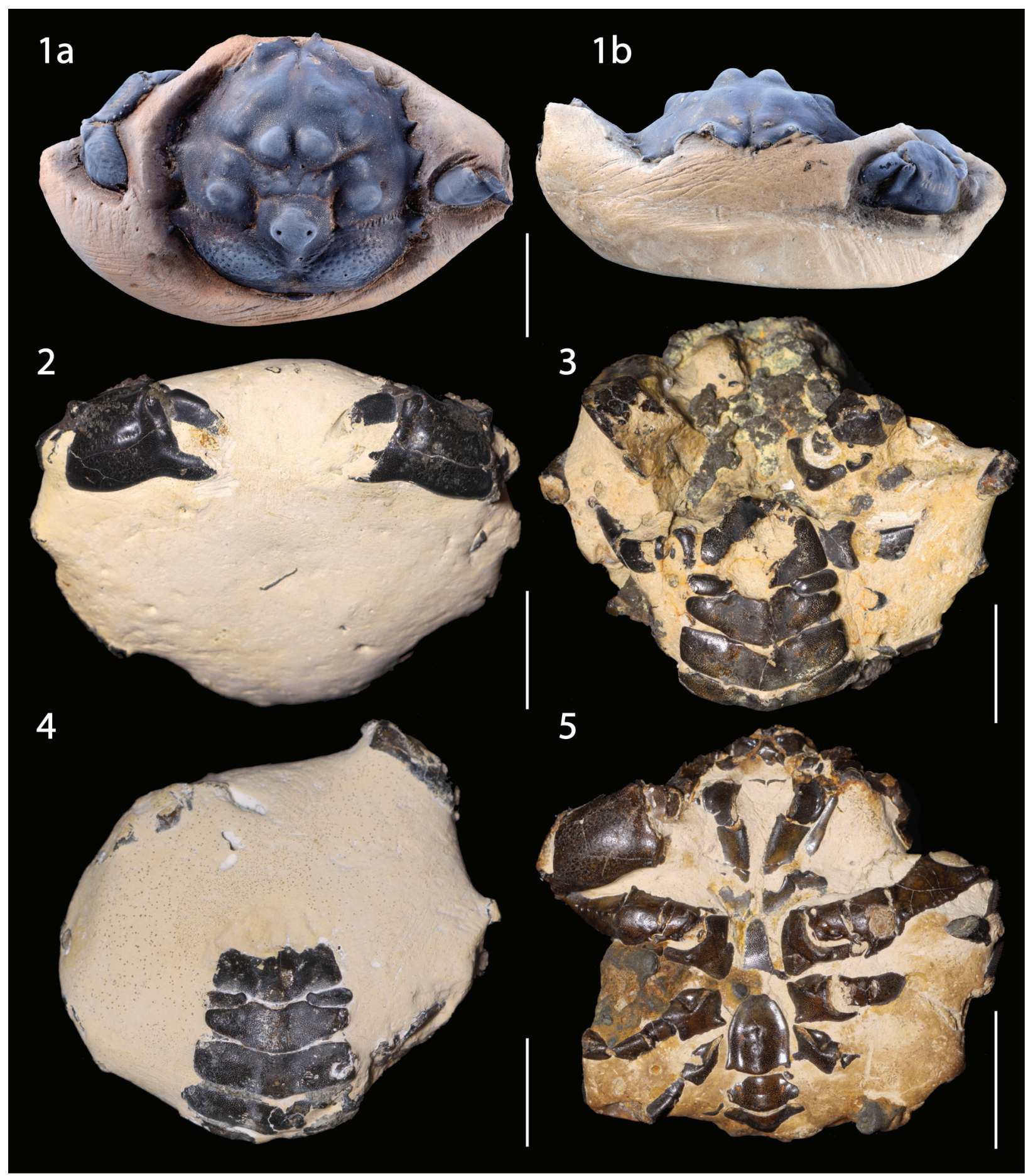

FIGURE 3. Dromilites belli n. sp. type series from the Ypresian London Clay (Division B1, Kent, United Kingdom). 1. Paratype MAB.k 3583 (Seasalter, foreshore exposure) coated with ammonium chloride: 1a. carapace in dorsal view, 1b. carapace in frontal view; 2. Paratype MAB.k 3584 (Seasalter, foreshore exposure): claws; 3. Paratype MAB.k 3585 (Seasalter,_foreshore exposure) (female individual): abdomen in ventral view; 4. Paratype MAB.k 3587 (Seasalter, foreshore exposure) (female individual): abdomen in ventral view; 5. Paratype MAB.k 3586 (Tankerton, foreshore exposure) (male individual): abdomen in ventral view. Scale bars equal $1 \mathrm{~cm}$. Photographs. Lilian Cazes (1) and Barry van Bakel (2-5). 
v. 1925 Dromilites bucklandi H. Milne Edwards; Gripp, p. 129.

v. 1928 Dromilites bucklandi H. Milne Edwards; Beurlen, p. 164.

v. 1929 Dromilites bucklandi H. Milne Edwards; Glaessner, p. 139.

v. 1945 Dromilites bucklandi H. Milne Edwards; Wrigley, p. 217.

v. 1966 Dromilites bucklandi H. Milne Edwards; Davidson, p. 211.

v. 1969 Dromilites bucklandi H. Milne Edwards; Glaessner, p. R487, fig. 297.3.

v. 1977 Dromilites bucklandi H. Milne Edwards; Cooper, p. 172.

v. 1982 Dromilites bucklandi H. Milne Edwards; Förster and Mundlos, p. 155.

v. 2006 Dromilites bucklandi H. Milne Edwards; Collins and Saward, p. 68-69, table 1.

v. 2009 Dromilites bucklandi H. Milne Edwards; Rayner et al., p. 56.

v. 2010 Dromilites bucklandi H. Milne Edwards; Schweitzer et al., p. 64.

v. 2010 Dromilites bucklandi H. Milne Edwards; Schweitzer and Feldmann, p. 422-432, fig. 2.

Etymology. The species name is dedicated to the British paleontologist Thomas Bell, who erected in 1858 the genus Dromilites previously proposed by $\mathrm{H}$. Milne Edwards (in 1837) by assigning species Dromia bucklandi and Dromia lamarckii to the genus.

Type material. Holotype: NHMUK PI OR 59089 (fig. 2.1) and 6 paratypes: NHMUK PI OR 59091 (fig. 2.2), MAB.k 3583-3587 (fig. 3).

Additional examined material. MNHN.F.R038534 and MNHN.F.A66911 (casts of specimens figured in Bell, 1858, Plate VI, figs. 8-10) (London Clay, Copenhagen Fields, London), 'specimen 1' figured in Rayner et al., 2009, p. 56 (London Clay, Division B1, Seasalter foreshore exposure, Kent, United Kingdom, $51^{\circ} 20^{\prime} 36.77^{\prime \prime} \mathrm{N} / 1^{\circ} 0$ '2.76"E) (see Table).

Description. Carapace subcircular, length and width subequal (holotype dimensions: $\mathrm{CL}=35.5$ $\mathrm{mm}, \mathrm{CW}=37 \mathrm{~mm}, \mathrm{FM}=18.5 \mathrm{~mm}$, OFM= $16 \mathrm{~mm}$, $\mathrm{PM}=20.5 \mathrm{~mm}$ ), maximum width at midlength to in posterior half, strongly convex in longitudinal and transverse cross sections; orbitofrontal margin prominent, wide, $43 \%$ maximum carapace width. Rostrum projected beyond orbits, broadly triangular, bilobed, axially notched, frontal margin with four triangular sharp teeth, median two from rostrum advanced; orbits forwardly, outwardly directed, upper orbital margin concave, outer orbital corner pointed. Lateral margin prominent; anterolateral margin weakly arched, with four strong, triangular, broad-based teeth; two anterior, two posterior the cervical notch; third lateral spine largest, flattened, more anteriorly directed. Posterolateral margin rounded in cross section, conspicuously short, strongly curved towards posterior margin, anteriorly bearing single prominent tooth. Posterior margin narrower than orbitofrontal margin, straight, distinctly rimmed.

Carapace regions strongly swollen, distinctly marked by large, rounded tubercles, deep, wide groove system; small epigastric swellings bounding anterior mesogastric process, mesogastric region narrowly triangular, posterior mesogastric region large, wide, strongly vaulted, with two large horizontally lined prominent tubercles, divided by short distinct median groove. Protogastric regions with two low tubercles, one anteriorly, one posteriorly, wider spaced; hepatic region flat, inclined. Metagastric region trapezoidal, wide anteriorly, posterior margin concave, arched, surface wrinkled. Urogastric region undefined. Cardiac region distinctly defined, large, strongly inflated, diamondshaped, apex pointed posteriorly, large central tubercle bearing two horizontally lined pits; intestinal region small, depressed. Branchial region large, subdivided by oblique postcervical, branchial grooves; epibranchial, mesobranchial regions bearing single large tubercle, mesobranchial tubercle largest, wider spaced, laterally marked by large pit; metabranchial region wide, short, conspicuously swollen, bearing numerous pits.

Cervical groove widely V-shaped, deep, distinct on medial carapace, interrupted at axis by gastric pits, faint laterally, weakly notching carapace margin; branchial grooves subparallel to cervical groove, wider, distinctly notching lateral margin; post-cervical grooves shallow, indistinct, separating branchial tubercles; branchiocardiac grooves conspicuously deep, anteriorly longitudinally directed, weakly concave, posteriorly converging to posterior margin.

Carapace epicuticle with numerous evenly spaced setal pits. Internal mold smooth.

Third maxillipeds long, pediform, coxae large, flabelliform, endopod robust, exopod slender, elongate. Chelipeds well developed, sub-homochelous, merus subtriangular in cross section; manus outer surface smooth, bulbous, spine on proximal upper surface; pollex scoop-shaped, pointed teeth on occlusal surface; dactylus curved. Pereiopods two, three moderately sized, pereiopod four, five reduced, carried subdorsally. Distal ends not preserved, most probably subchelate. 
Male sternum narrow, sternite four elongate, rounded, posterior sternites strongly curved. Male pleon narrow, telson longer than wide, reaching base of chelipeds; somite six long, uropods dorsally visible, small; somites four and five short, wide. Female pleon moderately wide; telson conspicuously large, longer than wide, reaching anterior end of coxae of chelipeds; somite five rectangular; somite six with large, triangular uropods.

Range. London Clay, Ypresian, lower Eocene.

Occurrence. London basin.

Remarks. This new species is assigned to Dromilites based on the following morphological characters: a carapace slightly wider than long; a bidentate rostrum; the anterolateral margins with widened teeth, an entire cervical groove, the carapace regions well defined, with sharp tubercles, and a prominent cardiac region. Dromilites belli $\mathrm{n}$. $\mathrm{sp}$. is morphologically closest to the species Dromilites montenati Robin, Van Bakel, Pacaud, and Charbonnier, 2016 in showing comparable highly defined carapace regions with marked tubercles, but differs in displaying four anterolateral (instead of five) and one posterolateral teeth (instead of none), prominent tubercles on the posterior mesogastric region, a less defined urogastric region, a more carved cardiac region with a large central tubercle bearing two horizontally lined pits, epibranchial and mesobranchial regions bearing a single large tubercle (instead of two); and in having cervical and branchial grooves notching the lateral carapace margins less and more distinctly respectively. Dromilites belli n. sp. differs from $D$. bucklandii, D. pastoris and ?D. cardwelli in having less distinct grooves, in particular a much weaker cervical groove, and distinctly vaulted carapace regions with strong tubercles (weakly vaulted carapace regions, without distinct tubercles in $D$. bucklandii, $D$. pastoris and ?D. cardwelli) in all size ranges. $D$. belli $\mathrm{n}$. sp. differs from $D$. vicensis in having a relatively shorter carapace (however, ratio length/width varies considerably; see Table), a well-defined mesogastric region, a distinctly vaulted cardiac region, and presence of strong tubercles.

The London Clay dromiid crabs are morphologically very similar. There are a number of differences by which $D$. belli $\mathrm{n}$. sp. and $D$. bucklandii are separated. The anterolateral margin in $D$. bucklandii has three teeth instead of four in $D$. belli $\mathrm{n}$. sp., in which only a single tooth is present between the cervical and branchial grooves. This third anterolateral tooth in $D$. bucklandii is flattened posteriorly, giving a flanged appearance. The posterolateral margin in $D$. belli is strongly curved, whereas it is anteriorly straight in $D$. bucklandii. This results in a relatively wider posterior margin in $D$. bucklandii. The single posterolateral tooth, just posterior the branchial groove, is subtle in $D$. bucklandii, while it is well-developed in the second species. The carapace regions in $D$. bucklandii are weakly vaulted, whereas they are strongly inflated in $D$. belli $\mathrm{n}$. $\mathrm{sp}$. Also the mesogastric region is undefined in $D$. bucklandii while it is visible in $D$. belli $\mathrm{n}$. sp. Large, coarse tubercles mark the gastric and branchial regions in $D$. belli, while these are absent in $D$. bucklandii. Finally, there are two weak bumps with a pit on the cardiac region of $D$. bucklandii; these are merged into one strongly inflated tubercle in $D$. belli $\mathrm{n}$. sp.

\section{DISCUSSION AND CONCLUSIONS}

A range of carapace sizes belonging both to males and females of $D$. bucklandii and $D$. belli $\mathrm{n}$. sp. have been examined in this study (Table), including specimens of both species which are subequal in size (e.g. MNHN.F.B21561 and MAB.k 3583; 21.5 and $21 \mathrm{~mm}$, respectively; see also Appendix for comparison). Ontogenetic differences are present in these two species, especially in $D$. belli $\mathrm{n}$. sp. These differences have already been discussed in Bell (1858, p. 32: for $D$. belle n. sp.) raising the fact that adult and young individuals might readily be taken for distinct species. Many of the tubercles, which are distinct, and even prominent in the small specimens, are lowered, expanded, in the larger. In the smaller specimens, the frontal and lateral teeth are distinctly more pronounced and spiny than in larger specimens. The claws are more slender in juveniles; in larger specimens the claws are large and robust. On the dorsal carapace, the tubercles are more acute in smaller specimens. In larger individuals, the tubercles on the protogastric and epibranchial regions are weak or even absent. The metabranchial region is strongly inflated in smaller specimens, and somewhat weaker in large individuals. These differences are seen in both sexes, so here considered as ontogenetic variation. This variation does not overlap the two species, ruling out the possibility that the species could be conspecific and that the morphotypes could correspond to sexual or ontogenetic variations. Also, only specimens with well-preserved cuticle are examined; thus the characters of each species, and differences between the two species, are no reflection of preservational incidence. Thus, Dromilites belli n. sp. is clearly distinguished from D. bucklandii, to which Milne Edwards was actually referring 180 years ago 
when he named what would become the type species of this dromioid crab genus.

\section{ACKNOWLEDGMENTS}

We are grateful to L. Cazes, photographer at the UMR 7207-CR2P (Paris), for providing 3D models of the types of $D$. bucklandii and $D$. belli $\mathrm{n}$. sp., as well as many of the specimen-pictures. We also want to thank P. Hurst and C. Mellish for providing us the new photographs of the types of $D$. belli $\mathrm{n}$. sp. deposited in at the NHM, London and warmly thank S. Polkowsky (Schwerin, Germany) for his kind donation of paratype MAB.k 3583.

\section{REFERENCES}

Armstrong, A., Nyborg, T., Bishop, G.A., Ossó-Morales, À., and Vega, F.J. 2009. Decapod crustaceans from the Paleocene of Central Texas, USA. Revista Mexicana de Ciencias Geológicas, 26(3): 745-763.

Barnolas Cortinas, A. 1973. Dromilites vicensis n. sp., nuevo Braquiuro del Eoceno marino de Cataluna. Instituto de Investigaciones Geologicas, 28: 5-13.

Bell, T. 1858. A monograph of the fossil malacostracous Crustacea of Great Britain, Part. I, Crustacea of the London Clay. Monograph of the Palaeontographical Society, London.

Beurlen, K. 1928. Die fossilen Dromiaceen und ihre Stammesgeschichte. Palaöntologische Zeitschrift, 10:144-183.

Carter, J. 1898. A contribution to the palaeontology of the decapod Crustacea of England. Quarterly Journal of the Geological Society, 54:15-44.

Collins, J.S.H. and Saward, J. 2006. Three new genera and species of crabs from the lower Eocene of London Clay of Essex, England. Bulletin of the Mizunami Fossil Museum: 33:6776.

Cooper, J. 1977. The Palaeontology of the London Clay (Lower Eocene) of the Herne Bay coastal section, Kent, England. Proceedings of the Geologists' Association, 88(3):163-178.

Davidson, E. 1966. A new Paleocene crab from Texas. Journal of Paleontology, 40(1):211-213.

de Haan, W. 1833-1850. Crustacea, p. 1-243. In Siebold, P.F., von (ed.), Fauna Japonica sive Descriptio Animalium, quae in Itinere per Japoniam, Jussu et Auspiciis Superiorum, qui Summun in India Batava Imperium Tenent, Suscepto, Annis 1823-1830 Collegit, Notis, Observationibus e Adumbrationibus Illustravit. Lugduni-Batavorum, Leiden.

Förster, R. and Mundlos. R. 1982. Krebse aus dem Alttertiär von Helmstedt und Handorf (Niedersachsen). Palaeontographica (A), 179:148-184.

Glaessner, M.F. 1929. Crustacea Decapoda, p. 1-464. In Pompeckj, F.J. (ed.), Fossilium Catalogus: Animalium, pars 41. W. Junk, Berlin.

Glaessner, M.F. 1969. Decapoda, p. R400-R533, R626-R628. In Moore, R.C. (ed.), Treatise on Invertebrate Paleontology R(4)(2). Geological Society of America and University of Kansas Press, Boulder and Lawrence.

Gripp, K. 1925. Über das Alttertiär von Hannover, ein Beitrag zur Stratigraphie Nordwestdeutschlands. Jahresbericht niedersächsisches Geologisches Verein, 17:127-138.

Guinot, D. 1977. Propositions pour une nouvelle classification des Crustacés Décapodes Brachyoures. Comptes Rendus de l'Académie des Sciences de Paris, D, 285:1049-1052.

Guinot, D. and Tavares, M. 2003. A new subfamilial arrangement for the Dromiidae de Haan, 1833, with diagnoses and descriptions of new genera and species (Crustacea, Decapoda, Brachyura). Zoosystema, 25:43-130.

Guinot, D., Tavares, M., and Castro P. 2013. Significance of the sexual openings and supplementary structures on the phylogeny of brachyuran crabs (Crustacea, Decapoda, Brachyura), with new nomina for higher-ranked podotreme taxa. Zootaxa, 3665:1-414.

Latreille, P.A. 1802. Histoire Naturelle Générale et Particulière des Crustacés et des Insectes: Ouvrage Faisant Suite aux CEuvres de Leclerc de Buffon, et Partie du Cours Complet d'Histoire Naturelle Rédigé par C. S. Sonnini, Mambres de Plusieurs Sociétés Savantes. Dufart F., Paris, $394 \mathrm{p}$.

Milne Edwards, H. 1834-1840. Histoire Naturelle des Crustacés, Comprenant l'Anatomie, la Physiologie, et la Classification de ces Animaux, Tome 2. Paris, $531 \mathrm{p}$.

Milne Edwards, H. 1837b. Description of Dromilites. L'Institut, Journal Universel des Sciences et des Sociétés Savantes en France et à l'étranger, 1ere section, Sciences, mathématiques, physiques, naturelles, 5:255. 
Milne Edwards, H. 1837c. Zoologie: Crustacés. Bulletin de la Société Philomatique de Paris, Extraits des Procès-Verbaux des Séances Pendant l'Année 1837, Séance du 8 juillet 1837: 115-116.

Milne Edwards, H. 1838. Classe huitième, Histoire des Crustacés. In Lamarck, J.B.P.A., de (ed.), Histoire Naturelle des Animaux sans Vertèbres 5 (second edition). Verdière, Paris, 612 p.

Müller, P. and Collins, J.S.H. 1991. Late Eocene coral-associated decapods (Crustacea) from Hungary. Contributions to Tertiary and Quaternary Geology, 28(2-3):47-92.

Ossó, À, van Bakel, B.W.M., Ferratges-Kwekel, F.A. and Moreno-Bedmar, J.A. In Press. New decapod assemblage from the lower Aptian of La Cova del Vidre (Baix Ebre, Tarragona Province, Catalonia, NE Iberian Peninsula).

Quayle, W.J. and Collins, J.S.H. 1981. New Eocene crabs from the Hampshire Basin. Palaeontology, 24(4):733-758.

Quayle, W.J. and Collins, J.S.H. 2012. A review of the decapod crustaceans from the Tertiary of the Isle of Wight, Hampshire, UK, with description of three new species. Bulletin of the Mizunami Fossil Museum, 38:33-51.

Rayner, D., Mitchell, T., Rayner, M., and Clouter, F. 2009. London Clay Fossils of Kent and Essex. Caxton and Holmesdale Press and Medway Fossil and Mineral Society, Sevenoaks, $228 \mathrm{p}$.

Reuss, A.E. 1845. Die Versteinerungen der Böhmischen Kreideformationen, mit Abbildungen der Neuen Arten, mit 51 Lithographirten Tafeln. Schweizbart E., Stuttgart, 148 p.

Reuss, A.E. 1858. Über kurzschwänzige Krebse im Jurakalke Mährens. Sitzungsberichte der Kaiserlichen Akademie der Wissenschaften, (Mathematisch-Naturwissenschaftliche Classe), 31:5-13.

Reuss, A.E. 1859. Zur Kenntnis fossiler Krabben. I. Die Kurzschwdinzer der Kreideformationen. Denkschriften der Kaiserlichen Akademie der Wissenschaften Wien, 7:1-90.

Robin, N., van Bakel, B.W.M., Pacaud, J.M., and Charbonnier, S. 2016. Decapod crustaceans from the Paleocene (Danian) of the Paris Basin (Vigny stratotype and allied localities) and a limpet palaeoassociation. Journal of Systematic Palaeontology, 15(4):257-273.

Schröder, H. 1906. Erlaüterungen zur Geologischen Spezialkarte von Preussen. Feister, G., Berlin.

Schweitzer, C.E. and Feldmann, R.M. 2010. Sphaerodromiidae (Brachyura: Dromiacea: Dromioidea) in the fossil record. Journal of Crustacean Biology, 30(3):417-429.

Schweitzer, C.E. and Feldmann, R.M. 2012. Reappraisal of a Paleocene crab (Brachyura: Dromiacea) from Texas. Journal of Crustacean Biology, 32(4):591-595.

Schweitzer, C.E., Feldmann. R.M., Garassino, A., Karasawa, H., and Schweigert, G. 2010. Systematic List of Fossil Decapod Crustacean Species. Crustaceana Monographs 10. Brill, Leiden, $222 \mathrm{p}$.

Vía, L. 1959. Decápodos fósiles del Eoceno español. Boletín del Instituto Geológico y Minero de España, 70:331-402.

von Schlotheim, E.F. 1820. Die Petrefaktenkunde, auf ihrem jetzigen Standpunkte, durch die Beschreibung seiner Sammlung versteinerter und fossiler Überreste des Thier- und Pflanzenreiches der Vorwelt erlautert. Becker, Gotha, 437 p.

Wrigley, A. 1945. Some war-time exposures in London of Woolwich Beds and London Clay. Proceedings of the Geologists' Association, 56(4):214-218. 
VAN BAKEL ET AL.: EOCENE DROMIID CRABS REVISED

\section{APPENDIX.}

Photogrammetric reconstructions of Dromilites bucklandii $\mathrm{H}$. Milne Edwards, 1837 lectotype (MNHN.F. B21561, Ypresian of the Isle of Sheppey, Kent, UK) and Dromilites belli n. sp. (MAB.k 3583, Ypresian of Seasalter, Kent, UK). Photogrammetry. Lilian Cazes. Animated PDF file available at palaeo-electronica.org/content/2017/2077-eocene-dromiid-crabs-revised. 